\title{
Być \\ czy nie być \\ w strefie euro?
}

Sytuacja w światowej gospodarce zmienia się $\mathrm{i}$ jest to proces naturalny, ale kierunki tych zmian są coraz trudniejsze do przewidzenia $\mathrm{i}$ to jest coś nowego. Głównymi przyczynami takiego stanu rzeczy są, $z$ jednej strony niepewność co do kierunków polityki Stanów Zjednoczonych po wyborach prezydenckich 2016 roku, z drugiej zaś pojawienie się nowej sytuacji w Unii Europejskiej, polegającej na wystąpieniu tak ważnego państwa, jakim jest Wielka Brytania.

Brexit, ale i wydarzenia w Unii Europejskiej oraz poszczególnych państwach członkowskich powodują destabilizację warunków dla rozwoju społeczno-gospodarczego zarówno UE, jak i poszczególnych jej członków, w tym Polski. Czy to już jest kryzys? W pewnym sensie, tak. Ale czy nawet kryzys ma oznaczać odwrót od europejskiej integracji gospodarczo-walutowej?

W przeszłości, w światowej gospodarce było wiele cyklicznie powtarzających się kryzysów i pomimo tego gospodarka światowa ciągle się rozwija. Kluczową sprawą jest zatem sposób, w jaki walczy się z samym kryzysem. Dlatego powinniśmy formułować pytania o przyszłość polskiej gospodarki. W jakim kierunku powinna ona zmierzać, co jest dla naszego społeczeństwa bardziej korzystne, a co może być zagrożeniem? Wiedząc o tym, że narzędziem wzrostu dobrobytu społeczeństwa jest rozwój gospodarczy, to czy powinniśmy zmierzać $\mathrm{w}$ kierunku poluzowania relacji integracyjnych $\mathrm{w}$ ramach Unii Europejskiej, czy może jednak działać na rzecz ich umocnienia?

Polska, choć jest niezwykle ważnym ogniwem Unii Europejskiej jako największe państwo spośród grupy państw Europy Środkowej i Wschodniej, swojej pozycji nie ma zagwarantowanej na zawsze. O zagrożeniach dla polskiej gospodarki płynących ze strony finansów pisał na łamach kwartalnika Władysław Szymański [2016]. Pojawiają się nawet mocne sygnały, że może ona ulec wyraźnemu pogorszeniu, a to za sprawą podziału UE na grupy „różnych prędkości”. Niemcy, Francja, Włochy i Hiszpania, a więc kraje mające w ramach UE decydujący wpływ na podejmowane decyzje, wystąpiły właśnie z takim postulatem. Jeśli doszło by do takiego podziału, to Polska zostanie przesunięta do drugiego, a może nawet trzeciego „koszyka”. Jest to realne zagrożenie dla przyszłości polskiej gospodarki. Negatywne konsekwencje dotyczyć bowiem będą przedsiębiorstw, a tym samym mogą zahamować rozwój gospodarczy.

W tym stanie rzeczy odżywa dyskusja na temat przystąpienia Polski do strefy euro, czyli uczynienie kroku do przodu, by w ten sposób nie dopuścić do wyrzucenia nas z głównego „koszyka”. W tym 
numerze kwartalnika temu zagadnieniu poświęcone są dwa artykuły. Grzegorz W. Kołodko [2017] naświetla kwestie ekonomii i polityki konwersji złotego na euro, a Magdalena Hryniewicka [2017] pisze o korzyściach i kosztach przystąpienia Polski do strefy euro, ocenianych przez pryzmat polskich przedsiębiorstw.

W tym miejscu warto przypomnieć historię euro oraz warunki, jakie doprowadziły do jego pojawienia się na światowym rynku walutowym. Strefę euro utworzyło jedenaście państw: Austria, Belgia, Finlandia, Francja, Hiszpania, Holandia, Irlandia, Luksemburg, Niemcy, Portugalia oraz Włochy. W 2001 roku dołączyła Grecja, a następnie przystąpiło do niej siedem kolejnych państw: Słowenia (2007), Cypr (2008), Malta (2008), Słowacja (2009), Estonia (2011), Łotwa (2014) i Litwa (2015). Euro jest prawnym środkiem płatniczym w dziewiętnastu państwach tworzących Unię Europejską, co oznacza, że jest to wspólna waluta dla ok. $340 \mathrm{mln}$ Europejczyków. Euro zostało wprowadzone 1 stycznia 1999 roku, najpierw w formie transakcji bezgotówkowych, a 1 stycznia 2002 roku w formie gotówkowej w dwunastu krajach członkowskich UE. Do strefy euro nie należą: Dania i Wielka Brytania (na skutek uzyskania w 1993 roku klauzuli opt-out do Traktatu z Maastricht). Szwecje również obowiązują przepisy Traktatu z Maastricht w sprawie wspólnej waluty, ale 4 grudnia 1997 parlament tego kraju przyjął deklarację, że od 1 stycznia 1999 roku Szwecja nie będzie uczestniczyć w obszarze euro. Szwecja nie weszła też do EMI II, a w referendum konsultacyjnym, które odbyło się 14 września 2003, większość społeczeństwa zagłosowała przeciwko wprowadzeniu wspólnej waluty.

Waluta euro używana jest także w jedenastu krajach i terytoriach nie należących do UE. Są to: Watykan, Maroko, San Marino, Andora, Kosowo, Czarnogóra oraz francuskie posiadłości na Atlantyku i Oceanie Indyjskim, a także brytyjskie bazy wojskowe na Cyprze.

Polska jest w grupie siedmiu państw, które są zobowiązane do wejścia do strefy euro.

Strefa euro jest wspólną przestrzenią unijnych państw, które wprowadziły euro jako swoją walutę, gdzie Europejski Bank Centralny prowadzi niezależną politykę pieniężną. Podaż waluty w styczniu 2017 roku wynosiła 11,44 bln EUR [Tradingekonomics.org, 2017]. Na euro przypada ok. 27 proc. światowych rezerw walutowych. Jest zatem drugą walutą światowych rezerw walutowych, po dolarze amerykańskim.

Przyczyną podjęcia działań Europejskiej Wspólnoty Gospodarczej zmierzających do utworzenia w miarę autonomicznej strefy walutowej był kryzys światowego systemu walutowego oparte- 
go na porządku z Bretton Woods, z dominującą pozycją amerykańskiego dolara. Gdy Richard Nixon, ówczesny prezydent USA, zawiesił 15 sierpnia 1971 wymienialność dolara na złoto, tym samym zakończył funkcjonowanie systemu złotodewizowego w ramach Międzynarodowego Funduszu Walutowego.

Początkowo strefa nowej waluty europejskiej miała działać na zasadach „starego porządku”, jedynie mając względną autonomię. Okazało się to jednak niemożliwe. Stąd najpierw doprowadzono do wyodrębnienia własnej jednostki rozliczeniowej ECU, a następnie do powstania odrębnej waluty euro.

Wprowadzenie euro traktowane jest $\mathrm{z}$ jednej strony jako ogromny sukces integrującej się Europy. Ma poprawić efektywność gospodarowania poprzez zwiększenie konkurencyjności podmiotów gospodarczych funkcjonujących na obszarze Unii Europejskiej, a tym samym ma przyczynić się do wzrostu dobrobytu ogółu europejskiego społeczeństwa. Z drugiej zaś strony oceniane jest często jako „krok w przepaść”, „droga w nieznane”, „ślepa przyszłość” itp.

Pojawiła się więc konieczność ponownej analizy sensu istnienia strefy wspólnej waluty, która powstała w wyniku dobrowolnej rezygnacji suwerennych państw z emisji własnego pieniądza, a w ślad za tym, z kształtowania jego ceny. Z punktu widzenia Polski, analiza powinna dotyczyć poszukiwania argumentów za i przeciw przystąpieniu do tej strefy, ale taka analiza powinna mieć przede wszystkim, charakter merytoryczny, a nie formalny.

Od czasu entuzjastycznego podejścia do przystąpienia Polski do strefy euro minęło ponad 10 lat. Był opracowany już kalendarz dojścia do tej strefy, ale jego realizacja została zaniechana bezterminowo. Niewątpliwie na taki rozwój sytuacji wpłynął globalny kryzys finansowy, któ- ry dotknął również strefę euro. Obecnie zmieniły się uwarunkowania zarówno globalne, jak i wewnątrz samej UE.

Czas zatem na rzeczową dyskusję, na porównanie ówczesnych oczekiwań z tym, co zostało dzięki przystąpieniu zrobione, na czym się zawiedliśmy, gdzie ponieśliśmy straty w kontekście rozwoju społeczno-gospodarczego kraju. Kilka dni temu rozmawiałem z prezesem jednego z banków, który powiedział, że wówczas, kiedy większość była za wejściem Polski do strefy euro, on był przeciw, zaś teraz, kiedy większość jest przeciwna, on skłania się być za.

Obecnie gospodarka światowa, tym samym europejska i polska, wydaje się być na rozdrożu. Mamy więcej pytań niż odpowiedzi. G.W. Kołodko [2017] w swoim artykule pyta, czy globalizacja zaiste się cofa albo nawet ustaje, czy też jest i będzie kontynuowana?

Globalizacja jest procesem nieuchronnym, ale równolegle możemy mieć do czynienia ze wzrostem znaczenia ugrupowań regionalnych, zwłaszcza w Azji. W ślad za tym może dojść do wykreowania wspólnej regionalnej waluty, można sobie nawet wyobrazić, że stanie się nią jedna z walut narodowych, np. chiński yuan. Za tym spostrzeżeniem przemawia fakt, że obecnie obserwuje się wzrost udziału tzw. innych walut (poza USD, EUR, JPY) w światowych rezerwach walutowych.

To jest zagrożeniem dla gospodarki Unii Europejskiej. Dlatego jest potrzeba poszukiwania argumentacji naukowej, uzasadniającej konieczność daleko idącej integracji gospodarczej w Europie, zwłaszcza w ramach Unii Europejskiej. Jednym z ważnych przejawów tego pogłębiania powinno być umacnianie, a nie osłabianie strefy euro.

Znana jest strategiczna zasada, zgodnie z którą najlepszą formą obrony jest atak. Wzmacnianie integracji gospodar- 
czej leży w interesie Polski i nie jest w sprzeczności z poszukiwaniem nowych rozwiązań, w tym zasad funkcjonowania Unii Europejskiej.

Czy włączenie się Polski do pogłębiania integracji gospodarczej powinno wiązać się z przystąpieniem do strefy euro? G.W. Kołodko [2017] przedstawia argumenty przemawiające za takim scenariuszem. Są to argumenty rzeczowe, z którymi należy się zgodzić. Utrata części suwerenności ekonomicznej powinna zostać zrekompensowana korzyściami z posługiwania się wspólną walutą. Korzyści z posługiwania się wspólną walutą dla przedsiębiorstw działających w Polsce, na podstawie badań, przedstawiła M. Hryniewicka [2017]. Wskazała również na zagrożenia.

W przypadku przystąpienia Polski do strefy euro, niezwykle ważną kwestią - a może nawet najważniejszą - będzie kurs walutowy, po jakim nastąpiłoby przeli- czenie. Rozpatrując to z punktu widzenia statycznego, należałoby dążyć do wejścia przy jak najmocniejszym złotym. Stwarzałoby to komfort psychiczny, gdyż przy kursie wymiany 1 EUR do 1 PLN nasz majątek wyrażony $\mathrm{w}$ euro nominalnie miałby wartość bardzo dużą. Niestety, radość nasza trwałaby krótko. Przeliczenie przy tak silnym złotym spowodowałoby, że nasza gospodarka stałaby się niekonkurencyjna. Nasze towary byłyby zbyt drogie $\mathrm{w}$ stosunku do towarów $\mathrm{z}$ innych krajów, a tym samym proces bankructw przedsiębiorstw byłby nieuchronny.

Dlatego też do kursu wymiany należy podejść dynamicznie, czyli z punktu widzenia konkurencyjności gospodarki. Złoty nie może być też zbyt słaby, gdyż mógłby powodować inflację. Wydaje się, że w obecnej sytuacji społeczno-gospodarczej najkorzystniejszy byłby kurs w przedziale 4,0-4,2 złotych za euro.

Prof. Roman Sobiecki

\section{Bibliografia:}

1. Hryniewicka M. [2017], Polskie przedsiębiorstwa - koszty i korzyści przystapienia do strefy euro, „Kwartalnik Nauk o Przedsiębiorstwie”, nr 1(42).

2. Kołodko G.W. [2017], Ekonomia i polityka konwersji ztotego na euro, „Kwartalnik Nauk o Przedsiębiorstwie", nr 1(42).

3. Szymański W. [2016], Zagrożenia ptynące ze stron polskich finansów dla polskiej gospodarki, „Kwartalnik Nauk o Przedsiębiorstwie", nr 3(40).

4. Tradingeconomics [2017], Strefa euro - podaż pieniadza, "Trading Economics", http://pl.tradingeconomics.com/euro-area/money-supply-m3, dostęp 7/03/2017. 